\title{
Tumoral calcinosis simulating sarcoma
}

\author{
Sekhar S. ${ }^{1 *}$, Shamili M. ${ }^{2}$, Gouthami B. ${ }^{3}$, Latha C. ${ }^{4}$, Harshitha G. ${ }^{5}$ \\ DOI: https://doi.org/10.17511/jopm.2020.i01.15
}

\footnotetext{
${ }^{1 *}$ S.V.R. Raja Sekhar, Assistant Professor, Department of Pathology, GEMS and Hospital, Srikakulam, Andhra Pradesh, India.

2 M. Shamili, Assistant Professor, Department of Pathology, GEMS and Hospital, Srikakulam, Andhra Pradesh, India.

3 B. Gouthami, Assistant Professor, Department of Pathology, GEMS and Hospital, Srikakulam, Andhra Pradesh, India.

${ }^{4}$ Ch. Asha Latha, Assistant Professor, Department of Pathology, GEMS and Hospital, Srikakulam, Andhra Pradesh, India.

5 G. Harshitha, Postgraduate, Department of Pathology, GEMS and Hospital, Srikakulam, Andhra Pradesh, India.
}

Tumoral calcinosis is a rare clinical and pathological entity, characterized by deposition of calcium in different sites of human body particularly in peri-articular tissues. It incidence is usually seen in young adults as a slowly growing, painless, firm to bony hard mass. Asymptomatic when small in size but larger masses can cause pressure symptoms due to compression of surrounding tissues or restriction of mobility of the joints. It can be predicted by typical radiological findings with the help of serum calcium and phosphorus levels but is confirmed only by histopathological examination. Many times, it isn't very easy to diagnose this condition preoperatively and can be mistaken as soft tissue sarcoma both clinically and radiologically. Subtyping of this lesion depends on serum calcium, phosphorus levels, family history and co-morbid conditions like chronic renal failure.

Keywords: Tumoral calcinosis, Sarcoma, Serum calcium, Serum phosphorus

Corresponding Author

S.V.R. Raja Sekhar, Assistant Professor, Department of Pathology, GEMS and Hospital, Srikakulam, Andhra Pradesh, India.

Email: rajsanuvada@gmail.com
How to Cite this Article

Sekhar SVRR , Shamili M, Gouthami B, Latha CA,

Harshitha G. Tumoral calcinosis simulating sarcoma.

Trop J Pathol Microbiol. 2020;6(1):93-97.

Available From

https://pathology.medresearch.in/index.php/jopm/ar

ticle/view/392
To Browse

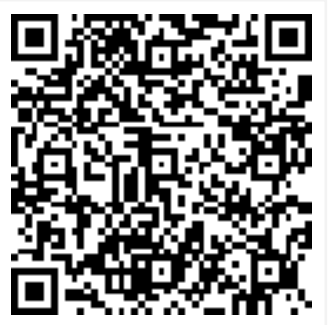

\section{Introduction}

Tumoral calcinosis, an uncommon disease, characterized by calcium salt deposition in different juxta-articular regions, particularly shoulder, elbow and hip joints [1]. Rarely spinal, metacarpal and popliteal joints are also involved. Skin and visceral organs are not affected. The exact cause for this disease is not known but various theories were proposed for its pathogenesis [2]. Normal serum calcium and phosphorus levels are seen in
Primary normo-phosphatemic tumoral calcinosis, which usually presents before 20 years of age. Mutations involving the gene encoding for SAMD9 protein show familial pattern in this variant [3]. Normal calcium and elevated phosphorus levels are seen in primary hyper-phosphatemic tumoral calcinosis, which usually presents in first and second decades. Hyperphosphatemia in this condition is due to mutation in Ga1NAc transferase 3 gene causing reduced urinary excretion of phosphate [4]. All the remaining
Manuscript Received 30-12-2019

Conflict of Interest No

Review Round 1
$10-01-2020$
Funding
Nil

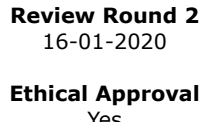

Yes
Review Round 3

Plagiarism X-checker $16 \%$
Accepted 20-01-2020 Note

(c) 2020 by S.V.R. Raja Sekhar, M. Shamili, B. Gouthami, Ch. Asha Latha, G. Harshitha and Published by Siddharth Health Research and Social Welfare Society. This is an Open Access article licensed under a Creative Commons Attribution 4.0 International License https://creativecommons.org/licenses/by/4.0/ unported [CC BY 4.0]. 
Causes are responsible for secondary tumoral calcinosis. Though this primary and secondary subtyping of tumoral calcinosis has similar picture histopathologically, they differ in the management. The reparative process, friction forces, calcifications and collagenoslysis causes dystrophic calcifications with cystic spaces surrounded by foreign body giant cell reaction, which represents the characteristic lesions of this entity.

The patients complained of slowly growing solitary or multiple swellings in the periarticular regions. Larger swellings cause surface skin ulceration or underlying tissue compression or limitation of joint movements. Radiologically, these lesions are multilobulated with cystic areas and calcifications near the joints [5]. The calcium layering in these cystic areas show fluid-fluid levels. Radiolabelled phosphate scintigraphy helps in identifying multiple lesions, active lesions and for monitoring the therapy. It can be misdiagnosed as a soft tissue sarcoma clinically or radiologically at times.

Also the other calcium related lesions can confuse clinicians as well as radiologists during diagnosing this condition. In such situations, histopathological examination confirms the diagnosis by showing liquid chalky contents and calcifications grossly, substantiated by cystic spaces, calcifications microscopically. Active disease process show surrounding foreign body giant cell reaction.

Hence, correlation of histopathological diagnosis with family history and biochemical findings is necessary in subtyping the lesion, which helps the managing that particular case. Here, the present case of Primary normophosphatemic tumoral calcinosis which was managed by surgical intervention.

\section{Case Report}

Clinical Features- A 20-year-old male came with a swelling in the right hip region for 4 years. It was not associated with pain but slowly increasing in size. There are no other swellings and no history of trauma or hemodialysis or any significant family history. On examination, the size of the swelling was $10 \times 8 \mathrm{~cm}$, well-demarcated. The skin over the swelling is normal. No scars are seen, no discharging sinuses present. The swelling is firm to hard in consistency, non-mobile, and the overlying skin is pinchable. The computed tomography showed a large soft tissue solid-cystic massmeasuring $7.8 \times 3.9 \times 3.5 \mathrm{~cm}$ in the periarticular
Region of the left hip joint with fluid-fluid levels and diagnosed as soft tissue sarcoma radiologically. Biochemically, serum levels of calcium and phosphorus were $9.8 \mathrm{mg} / \mathrm{dL}$ (normal range 9-11 $\mathrm{mg} / \mathrm{dL}$ ) and $4.3 \mathrm{mg} / \mathrm{dL}$ (normal range $4-7 \mathrm{mg} / \mathrm{dL}$ ), respectively. The patient underwent excision of the mass.

Gross- We received an irregular ovoid greytan mass measuring $8 \times 4 \times 4 \mathrm{~cm}$ (Figure 1 ). The cut surface was yellow to grey tan, solid, tiny cystic areaswith necrotic material (Figure 2). A gritty sensation felt during cutting.

Microscopy- The histopathology showed multiple cystic spaces (Figure 3) surrounded by extensive areas of dystrophic calcification with foreign body giant cell reaction (Figure 4), fibroblastic proliferation, necrosis, and mononuclear cell inflammation. There were no atypical cells or any increased mitotic activity. Histopathologic diagnosis of tumoral calcinosisis made. No recurrence is seen in the 1 year follow-up period.

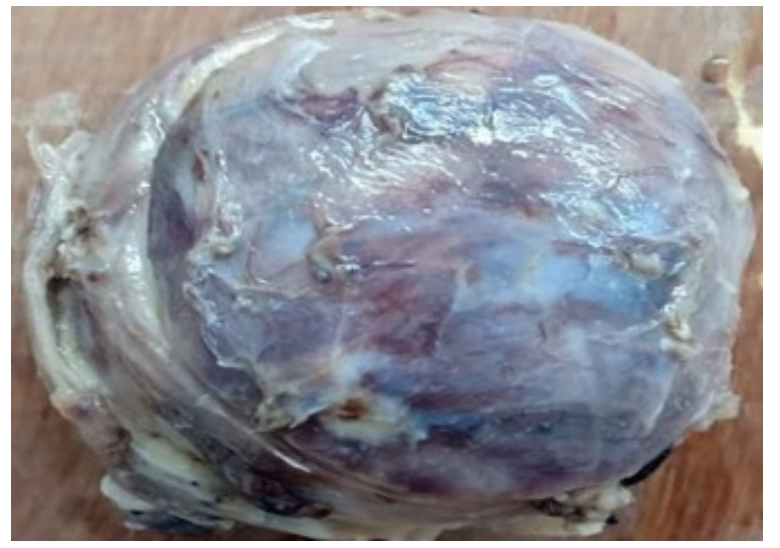

Fig-1: External surface of the grey-tan ovoid mass.

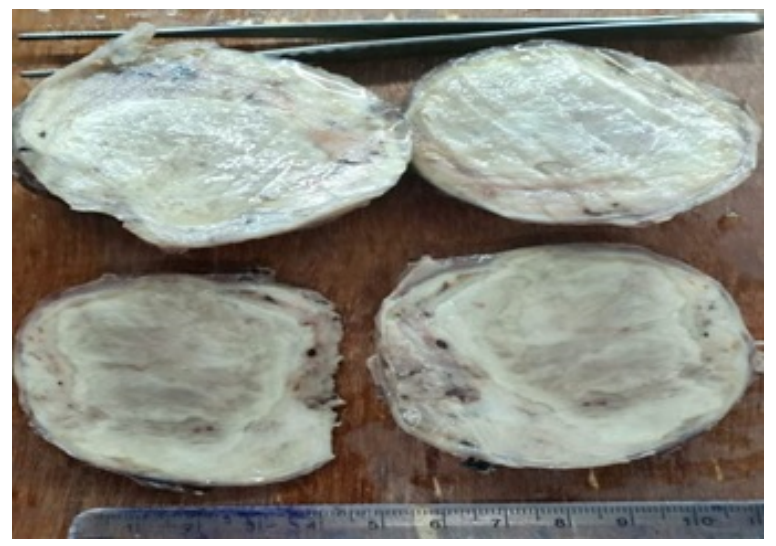

Fig-2: Cut section showing yellow white to 


\section{Grey-tan areas.}

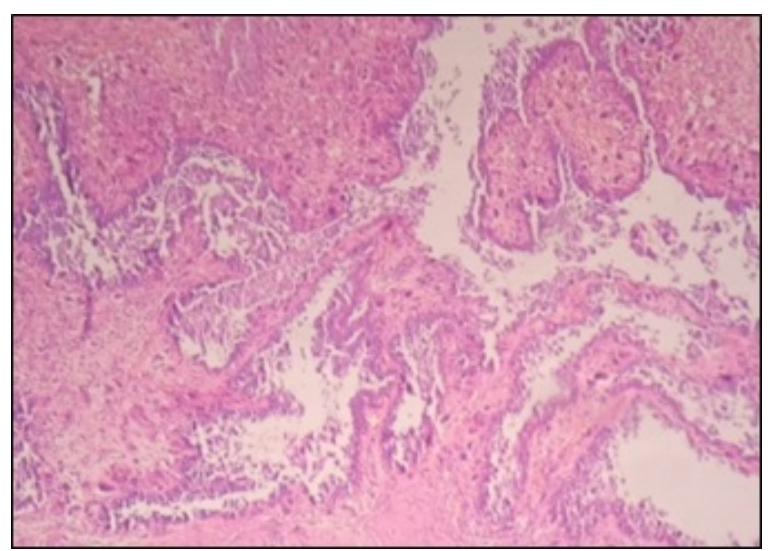

Fig-3: Cystic spaces with giant cell reaction.

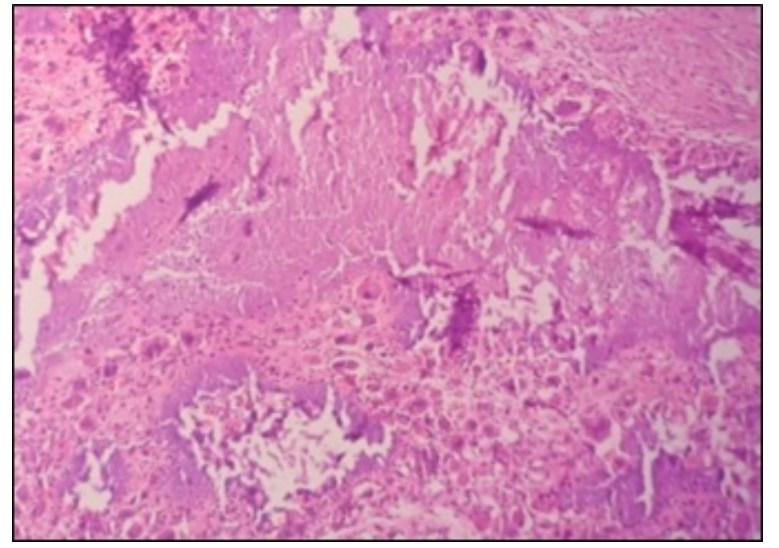

Fig-4: Dystrophic calcifications with giant cell reaction.

\section{Discussion}

Inclan et al was the first to coin the term "tumoral calcinosis" in 1943 [6]. Smack et al in 1996 proposed the pathogenesis-based classification [2]. Three subtypes have been described 1) Primary normophosphatemic tumoral calcinosis, which is usually sporadic, 2) Primary hyperphosphatemic tumoral calcinosis which is usually familial and 3 ) Secondary tumoral calcinosis which is secondary to diseases like chronic renal failure with hemodialysis, concurrent hyperparathyroidism, milk-alkali syndrome, and hypervitaminosis-D [7]. Due to the normal phosphate levels, no family history, and no recurrences, our patient was categorized as primary normophosphatemic tumoral calcinosis [7]. This disease usually presents as a small firm to hard mass in the subcutaneous plane of peri-articular regions of hip, shoulder, and elbow and gradually increases in size [8]. Though the lesion does not infiltrate into surrounding normal tissues, but large-
Sized mass can cause compression symptoms and can lead to pressure necrosis of underlying tissues, and can also ulcerate the surface skin $[9,10]$. These large tumoral calcinosis may be mistaken clinically and at times radiologically as a malignant neoplasm like osteosarcoma, synovial sarcoma [8] as happened in the present case or with other calcium deposition conditions. If the stalk that connects Parosteal osteosarcomas to underlying bone is not apparent, it can be confused with tumoral calcinosis. Cross-sectional images and the clinical history help in differentiating both these conditions. Even, Extraskeletal osteosarcomas may present as calcified soft-tissue masses and biopsy is generally required to establish the diagnosis in these cases. Involvement of bone or the presence of a noncalcified soft-tissue mass should distinct them radiologically [11]. Synovial sarcomas radiologically have a variable appearance, but they may show dense, lobulated calcification involving a part of the tumor. At MR imaging, most of these are poorly defined and infiltrative. Larger lesions are septated with areas of high signal intensity on T1-weighted MR images, which represent hemorrhage. About One-third tumors appear hyper-, iso-, and hypointense on T2-weighted MR images, representing solid, cystic, and fibrous elements with areas of hemorrhage. The presence of a noncalcified soft-tissue mass makes synovial sarcoma different from tumoral calcinosis radiologically [12]. Microscopically, classically the lesion shows a malignant mesenchymal neoplasm with epithelial and spindle cell components and can be easily distinguished from tumoral calcinosis. Myositis ossificans, characterized by heterotopic bone and cartilage formation in muscle. The localized form, myositis ossificans is usually secondary to injury. This lesion can be radiographically differentiated from calcinosis in tumoral calcinosis by its rapid evolution from faint calcification to organized cartilage and bone and lack of lobular morphology [13]. Late lesions, also called heterotopic ossification, are clearly different from tumoral calcinosis because of their organization into bone with a distinct cortex and medullary space. The characteristic sheet like distribution of calcinosis universalis and its involvement of muscle and fascial planes usually makes this condition distinct from tumoral calcinosis. Calcinosis circumscripta is described as firm, white dermal papules, plaques, or subcutaneous nodules found in a variety of distributions. These calcifications occur in connective tissue disease, most prevalently seen in 
The early stages of polymyositis but also in dermatomyositis, systemic lupus erythematosus, progressive systemic sclerosis, and CREST. Calcinosis circumscripta tends to be much less extensive and are typically located in the subcutaneous tissues rather than in bursal regions. Hydroxyapatite deposition within tendons and tendon sheaths is termedcalcific tendonitis. It occurs in up to $3 \%$ of adults and is the cause in up to $40 \%$ of painful shoulder syndromes. The locations affected in decreasing order of frequency include the shoulder, hip, elbow, wrist, and knee. The location within a tendon, the lack of sedimentation, and the clinical presentation make calcific tendonitis distinct from tumoral calcinosis [14]. Synovial osteochondromatosis is a proliferation of intrasynovial nodules of cartilage or of bone and cartilage caused by metaplastic, rather than neoplastic, changes of the synovium. It usually occurs within a joint or a tendon sheath, although when periarticular, it can mimic the calcinosis of tumoral calcinosis. Identification of the rings-andarcs morphology of the calcifications and of the intraarticular location makes synovial osteochondromatosis distinct from tumoral calcinosis at imaging [13]. Even on gross examination, it may be difficult to diagnose because of the grey-white necrotic areas which favour a malignant neoplastic lesion. But, any free-flowing opaque white chalky material shall prompt for the diagnosis of tumoral calcinosis [8].

Histopathologically, the lesion characteristically showsdystrophic calcifications with cystic spaces surrounded by foreign body giant cells and fibrosis. Thus, it can be distinguished from other causes of soft tissue calcification and absence of atypical cells and no increased mitosis rules out malignant neoplastic conditions. The microscopic features will not help in differentiating the three clinical subtypes [15]. These subtypes need to be distinguished as they differ in the management. Phosphate lowering drugs can help in the complete resolution of small lesions in subtypes 2 and 3 . While subtype 1 lesion and large size type 2 and 3 lesions need surgical intervention in the form of excision $[9,10,16]$. As our patient is categorized as subtype 1 , surgical management is done. To conclude, tumoral calcinosis can be misdiagnosed clinically, radiologically, and even grossly, sometimes making histopathological diagnosis mandatory for these lesions. Familial history and biochemical parameters help in subtyping the disease and thereby helps in the correct management of these patients.

\section{Reference}

01. Flemming DJ, Murphey MD, Shekitka KM, Temple HT, Jelinek JJ, Kransdorf MJ. Osseous involvement in calcific tendonitis- a retrospective review of 50 cases. AJR Am J Roentgenol. 2003;181(4)965-972.

doi:[Article:https://doi.org/10.2214/ajr.181.4.1810 965][Crossref]

02. Lykoudis EG, Seretis K, Ristanis S. Huge recurrent tumoral calcinosis needing extensive excision and reconstruction- Report of a rare case and brief literature review. Aesthetic Plast Surg. 2012;36(5)1194 1197.

doi: [Article:https://doi.org/10.1007/s00266-0129923-0][Crossref]

03. Hershkovitz D, Gross Y, Nahum S, Yehezkel S, Sarig $O$, Uitto $\mathrm{J}$ et al. Functional characterization of SAMD9, a protein deficient in normophosphatemic familial tumoral calcinosis. J Invest Dermatol. 2011;131(3)662-669.

doi: [Article:https://doi.org/10.1038/jid.2010.387] [Crossref]

04. Topaz O, Shurman DL, Bergman R, Indelman M, Ratajczak $P$, Mizrachi $M$ et al. Mutations in GALNT3, encoding a protein involved in O-linked glycosylation, cause familial tumoral calcinosis. Nat Genet. 2004;36(6)579-581.

doi: [Article:https://doi.org/10.1038/ng1358] [Crossref]

05. Liu X, Hong S, Chen G, Tu C. Large tumoral calcinosis and pathological femur fracture in a hemodialysis patient with secondary hyperparathyroidism. Int Surg J. 2015;2 (1)91 94.

doi:[Article:https://doi.org/10.5455/2349-2902.is j20150219][Crossref]

06. Smack D, Norton SA, Fitzpatrick JE. Proposal for a pathogenesis-based classification of tumoral calcinosis. Int J Dermatol. 1996;35(4)265-271. doi:[Article:https://doi.org/10.1111/j.1365-4362. 1996.tb02999.x][Crossref]

07. McClatchie S, Bremner AD. Tumoral calcinosisan unrecognized disease. Br Med J. 1969;1;153155.

doi:[Article:https://doi.org/10.1136/bmj.1.5637.142a][Crossref]

08. Jones BC, Sundaram M, Kransdorf MJ. Synovial sarcoma- MR imaging findings in 34 patients. AJR Am J Roentgenol. 1993;161;827-830. [Crossref] 
09. Olsen KM, Chew FS. Tumoral calcinosis- pearls, polemics, and alternative possibilities. Radiograph. 2006; 26(3)871-885.

doi: [Article:https://doi.org/10.1148/rg.263055099] [Crossref]

10. Kransdorf MJ, Meis JM. Extraskeletal osseous and cartilaginous tumors of the extremities. Radiograph. 1993;13(4)853-884.

doi:[Article:https://doi.org/10.1148/radiographics. 13.4.8356273][Crossref]

11. Inclan A, Leon PP, Camejo M. Tumoral calcinosis. J Am Med Ass. 1943;121;490-495. doi:[Article:https://doi.org/10.1001/jama.1943. 02840070018][Crossref]

12. Kannan $S$, Ravikumar $L$, Mahadevan $S$, Natarajan M, Satya A, Bhat R, et al. Tumoral calcinosis with Vitamin $D$ deficiency. Saudi J Kidney Dis Transpl. 2008; 19(6)960 963.

[Crossref]
13. Mohamed S, Jong Hun J, Weon Yoo K. Tumoral calcinosis of the foot with unusual presentation in an 11 year old boy- A case report and review of literature. J Postgrad Med. 2007;53(4)247 249.

doi: [Article:https://doi.org/10.4103/00223859.37513][Crossref]

14. Shaukat YM, Malik EF, Al Rashid M, Cannon SR. Large tumoral calcinosisin the gluteal region- $A$ case report. Ortop Traumatol Rehabil. 2013;15(5)495 499.

doi:[Article:https://doi.org/10.5604/15093492.1084 363][Crossref]

15. Chew FS, Roberts CC. Musculoskeletal imaginga teaching file- 2nd ed. New York, NY- Lippincott Williams \& Wilkins. 2006; 233.

[Crossref] 